\title{
Information and Communication Technology Word processing skills' In-Service Training for Computer Teachers in Secondary Schools in Nsukka Education Zone
}

\author{
Nwosu Ogochukwu $\mathrm{F}^{1^{*}}$, Osondu Stella Ifeoma $\mathrm{E}^{2}$, Nwanze Maureen $\mathrm{N}^{3}$

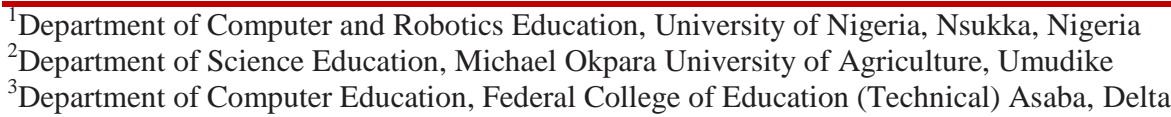

This paper focuses on the computer studies teachers ICT word processing skills of secondary school computer studies teachers in Nsukka education zone, Enugu state, Nigeria. The purpose of this study is to find out the ICT word processing skills needed by computer studies teachers in secondary schools in Nsukka education zone, Enugu state Nigeria. 120 copies of questionnaire were administered to computer studies teachers in 58 secondary schools, of which all were completed and returned. The findings of this study showed that computer studies teachers in secondary schools in Nsukka education zone needed in-service training in word processing skills which include: ability to create blank document from templates and from existing document, ability to cut, copy, paste text, move text by dragging and dropping, among others. The study concluded that secondary schools computer studies teachers needed in-service training in word processing skills for effective teaching and learning of computer studies in secondary schools in Nsukka educational zone. That the identified word processing skills should be used by curriculum planners at State and federal levels to further improve the existing curriculums at secondary in the State and the nation in general.

Keywords: Computer teachers, In-service training, Word processing, Skills.

Copyright $\left({ }_{0} 2021\right.$ The Author(s): This is an open-access article distributed under the terms of the Creative Commons Attribution 4.0 International License (CC BY-NC 4.0) which permits unrestricted use, distribution, and reproduction in any medium for non-commercial use provided the original author and source are credited.

\section{INTRODUCTION}

The world is already arising to be the century of the computer age. The computer uprising which started after the Second war is now developing exponentially and computers are launching to influence and take over nearly every aspect of our lives. Ugo [1], penned that "The Economic Commission for Africa has indicated that the supremacy to gain access to and use of information is no longer a luxury, but a necessity for development".

Computer studies is of dominant value to national progress and it is on this basis that the Federal government of Nigeria introduced computer studies in the education system starting from primary through to secondary schools [2]. In any educational system, the level of accessible resources places a constraints or limitation on the level to which learning can take place. Odia [3] suggests that information communication technology is of such significance to the expectations of industrial and commercial wellbeing of any nation that invest in the equipment, teacher education, and support services necessary for the effective delivery of an information communication technology based curriculum and as such should be ranked high in any set of government precedence.

Opara [2], suggests that as computer studies has been inculcated fully in Nigerian secondary schools, the computer device versus student ratio is small, funding by government has not been encouraging, computer education syllabus is unpopular among students and parents and thus hardly implemented, and teachers are inadequate to implement computer education because the requires basis skills in handling ICT facilities.

Computer studies was on the onset restricted to Federal unity Secondary schools until few years ago when it was introduced to states' government secondary school system. At the moment, Computer Studies is offered as a core subject in Basic School Certificate for those in junior secondary school level in Enugu state, Nigeria. This is because educational systems around the 
Nwosu Ogochukwu F et al., Sch J Eng Tech, Apr, 2021; 9(4): 46-50

world are on increasing force to use the new information and communication technologies (ICTs). Teachers, teaching computer studies in secondary school, are to be exposed to wider knowledge of using computer in their teaching surroundings. On the contrary, in Nsukka educational zone of Enugu state, secondary school teachers need to get hold on both proficiency of the subject matter and the instructive skills which will allow them expound the material to students at right and proper stage of learning [4].

Opera [2], opined that it has been realized by educators that the awareness of how to use technological tools is not enough, that what is really needed is the capability of using these tools successfully and efficiently to make smooth the progress of learning processes of their pupils. Hence, study interest has on ways to out together technological tools in teaching.

Majority of computer studies teachers in secondary schools in Nsukka educational zone of Enugu state cannot teach computer studies as a subject because they are not competent in basic computer operation such as knowing their ways around word processing and the use of simple application software [5]. Computer studies teachers require knowing the basic skill and access to information and communication technology infrastructure for their need to live as a people in a world undergoing swift transformations due to increased use of information communication technology, their need to entrench information communication technology use in their teaching and administrative duties and, increasingly, their need to use information communication technology in their professional studies [6].

Word Processing refers to the actions of using a computer to create, edit, save and print documents. In order to achieve the functions of word processing, specialized software (known as a Word Processor) is needed. An example of a Word Processor is Microsoft Word, though other word processing applications are also broadly used [7].

Based on the study, emphasis will be more on secondary education. Secondary- education is the level of education which children enter into after their primary education, but before the tertiary level. It has two stages of three years duration each; the junior secondary and the senior secondary. The two broad aims of secondary education are; Preparation of students for useful living with the society, and Preparation of students for higher education [8]. To achieve these aims, Ogunsola [9], stated that the Federal Government of Nigeria inculcated computer literacy program in secondary school curriculum. ICT is an integral component of computer studies which will enhance quality teaching and learning on the part of the teachers and learners.
The author further stated that the problems of secondary school teachers' inability and inefficiency in imparting to students the desirable ICT skills include: absence of the provision of the basic Information and Communication Technology components and skills expected of the teachers, of which word processing is among. Most institutions lack computer literate teachers and ICT experts that would support and manage the internet connectivity and/or application of computing in the teaching and learning process. Limited funds available to secondary schools have hindered the provision of needed facilities and infrastructure to promote ICT usage. A close observation by the researcher during preliminary investigation for the study revealed that most secondary schools in Nsukka do not have equipped laboratory for ICT. Classrooms are equally not equipped for ICT usage. Thus, teachers do not effectively utilize ICT in teaching in the schools. This calls for ICT in-service training for computer teachers in secondary schools in Nsukka Educational zone of Enugu State.

Kyunghoon [10], while discussing the need for in-service training maintained that public programme do not remain static. He started that they change often as a result of legislation and in order to adapt to the changing situation, employees have to undergo inservice training. Also as a result of technological change, technology is always changing and employees must keep abreast of this, it is through training that specialist keep abreast of their specialty and avoids limitations of the narrow experts. Refresher courses and professional conferences can also serve this purpose. ICT is a recent phenomenon in Nigeria and the only way to get secondary school teachers abreast with the intricacies of information and communication technology, is to expose them to in-service training.

Olakulehin [11], defined In-service training as training or courses of study done while somebody is working in a job, to enable one learn new skills. Inwent [12], stated that the ever increasing rate of technological changes, the increasing scope of governmental activities and the ceaseless clamor for social change make it necessary for workers to be prepared for adaptability to enable them cope with the problems of change. Eneje [13], stated that most of the computer studies teachers in Nsukka educational zone are not familiar with some of the functions of word processing software which includes; creating, editing, saving and printing documents, copying, pasting, moving and deleting text within a document, formatting text, such as font type, bolding, underlining or italicizing, creating and editing tables, inserting elements from other software, such as illustrations or photographs, correcting spelling and grammar.

Word processing include tools to format your pages. For instance, you can organize your text into columns, add page numbers, insert illustrations, etc. on 
Nwosu Ogochukwu F et al., Sch J Eng Tech, Apr, 2021; 9(4): 46-50

the other hand, word processing does not give you complete control over the look and feel of your document. One may need to use desktop publishing software to give you more control over the layout of your pages, when design becomes of importance.

Word processing software of course contains features to make it easier for you to perform repetitive tasks. For example, when one needs to send a letter to all customers regarding a new procedure, the letter will be the same for all customers except for the name and address will be different. You will see that s mail merge function allows you to generate all the letters using one template document and a table with customer names and addresses in the database.

Text editors is not the same with word processing software. They both do allow you to create, edit and save text documents, they only work on plain text. Text editors do not make use any formatting, such as underlined text or different fonts. Text editors does a different thing from word processing software.

Nsukka Educational zone of Enugu state have a good percentage of secondary school computer studies teachers who are not skilled or exposed to the use of technology. This is as a result of the government inability to expose the computer studies teachers to the necessary in-service training needs for pregression. Among the inhibitors that prevent this revolution from becoming widespread and comprehensive are inadequate provision of the basic and the most fundamental in-service training in computer appreciation, for computer teachers.

Secondary school in Nsukka are so well equipped with computers and its accessories, but when one take a closer look, one finds out that the computer laboratories are not used, teachers shy aware from using these computers to teach. In most cases, students are more skilled than the computer studies teachers that teaches them. Even as government have inculcated computer studies in secondary schools, that Nsukka is lagging behind as per the use of these computers in teaching. So these calls for word processing skills inservice training needs for computer studies teachers in secondary schools in Nsukka.

\section{MATERIAL AND METHOD}

This study was used in investigating Computer studies teachers' in-service training needs in computer appreciation skills in secondary schools in Nsukka education zone. A questionnaire was designed and distributed to targeted audience who are computer studies teachers in secondary schools. One hundred and twenty copies of the questionnaire were distributed among the computer studies teachers. The was a $100 \%$ of completed questionnaire were, returned and found utilizable. The study design is survey research method and the population of the study is 120 computer studies teachers.

\section{AREA OF STUDY}

This study was carried in Nsukka education zone, Enugu state Nigeria. In Nsukka educational zone, computer studies is taught in the three local government area that made the education zone; namely Igbo-Etiti, Nsukka, and Uzo-Uwani local government areas. This three local government area have 58 government owned secondary schools. Computer studies is taught by computer studies teachers holding degrees in Computer Education, Computer Science with a Professional Diploma in Education, masters in Computer education. Secondary education in Nigeria is divided into two; the Junior secondary and the senior secondary. Computer studies in taught in both junior and senior secondary schools.

\section{ANALYSIS AND RESULTS}

Out of the 120 copies of the questionnaire distributed to the respondents, all were completed, returned and found useable for the purpose of this analysis. The age bracket of the respondents was, 25-35 $(19.12 \%)$ while $36-45 \quad(42.64 \%)$ and 46-above $(38.24 \%)$.A higher number of female $36(34.94 \%)$ as against $32(45.06 \%)$ males, constitute the study's respondents.

Table-1: Mean Ratings of the Respondents on In-service Training Needs of Computer Teachers in Word Processing Skills in Secondary School in Nsukka Educational Zone $(\mathrm{N}=120)$

\begin{tabular}{|l|l|l|l|l|}
\hline SN & Word Processing Skills & $\mathbf{X}$ & SD & Remarks \\
\hline 1 & $\begin{array}{l}\text { Ability to create blank document from templates and from existing } \\
\text { document. }\end{array}$ & 3.64 & 0.57 & Highly Needed \\
\hline 2 & Ability to cut, copy, paste text, move text by dragging and dropping. & 3.55 & 0.59 & Highly Needed \\
\hline 3 & Able to use the office clip board, find and replace text. & 3.22 & 0.57 & $\begin{array}{l}\text { Averagely } \\
\text { Needed }\end{array}$ \\
\hline 4 & Ability to use the format painter, add and drop cap to text. & 3.65 & 0.57 & Highly Needed \\
\hline 5 & Applying a quick style to text and align and justify text. & 3.54 & 0.59 & Highly Needed \\
\hline 6 & Being able to interact with words and the use of advanced formatting. & 3.59 & 0.58 & Highly Needed \\
\hline 7 & $\begin{array}{l}\text { Being able to navigate through document using the mouse, keyboard and } \\
\text { scroll bar. }\end{array}$ & 3.37 & 0.59 & $\begin{array}{l}\text { Averagely } \\
\text { Needed }\end{array}$ \\
\hline 8 & $\begin{array}{l}\text { Ability to create new documents, save document, open files and close } \\
\text { documents. }\end{array}$ & 3.68 & 0.57 & Highly Needed \\
\hline
\end{tabular}


Nwosu Ogochukwu F et al., Sch J Eng Tech, Apr, 2021; 9(4): 46-50

\begin{tabular}{|l|l|l|l|l|}
\hline SN & Word Processing Skills & $\overline{\mathbf{X}}$ & SD & Remarks \\
\hline 9 & Ability to identify window icons and their functions. & 3.70 & 0.66 & Highly Needed \\
\hline 10 & $\begin{array}{l}\text { Being able to correctly and systematically name and locate files and close } \\
\text { documents. }\end{array}$ & 3.42 & 0.63 & $\begin{array}{l}\text { Averagely } \\
\text { Needed }\end{array}$ \\
\hline 11 & Ability to read typed document. & 3.40 & 0.59 & $\begin{array}{l}\text { Averagely } \\
\text { Needed }\end{array}$ \\
\hline 12 & Ability to listen and respond to verbal language. & 3.69 & 0.58 & Highly Needed \\
\hline 13 & Ability to interpret written information, eg. Manual, graphs. & 3.56 & 0.59 & Highly Needed \\
\hline 14 & Ability to communicate thoughts into massage. & 3.29 & 0.56 & $\begin{array}{l}\text { Averagely } \\
\text { Needed }\end{array}$ \\
\hline & Cluster Summary & 3.57 & 0.58 & Highly Needed \\
\hline
\end{tabular}

Data presented in Table-1 showed that the mean ratings of the responses of the respondents on 9 out of the 14 identified word processing skills had mean values that ranged from 3.54 to 3.70 which fell within real limit of number $3.50-4.00$. This indicated that computer teachers highly needed in-service training on the 9 identified word processing skills in Secondary schools in Nsukka education zone. The mean values of the remaining 5 word processing skills ranged from 3.22 to 3.42 which fell within real limit of number 2.50 - 3.49. This showed that the computer teachers averagely needed in-service training skills in the remaining 5 word processing skills in Secondary schools in Nsukka education zone of Enugu State. The standard deviation values of the 14 items in the table ranged from 0.56 to 0.66 which indicated that the responses of the respondents are close to one another and to the mean.

\section{DISCUSSION}

The findings of this study showed that computer studies teachers in secondary schools in Nsukka education zone needed in-service training in word processing skills which include: ability to create blank document from templates and from existing document, ability to cut, copy, paste text, move text by dragging and dropping, using the office clip board, find and replace text, ability to use the format painter, add and drop cap to text, being able to interact with words and the use of advanced formatting, being able to navigate through document using the mouse, keyboard and scroll bar, ability to identify window icons and their functions, ability to listen and respond to verbal language and ability to communicate thoughts into massage among others.

\section{CONCLUSION}

There is adequate number of computer teachers in secondary schools in Nsukka but without sufficient ICT skills to use the available ICT facilities in the school for meaningful instructional delivery. This might have resulted from the teachers' inability to get exposed to the necessary ICT advancement programmes through in-service training for skill update. It is against this background that this study was carried out to identify ICT skills in computer appreciation, word processing, spreadsheet and internet communication where secondary school computer teachers needed inservice training for effective teaching of computer in secondary schools in the study area.

The study thereby concluded that secondary schools computer teachers needed in-service training in computer appreciation, word processing, spreadsheet and internet communication skills for effective teaching and learning of computer studies in secondary schools in Nsukka educational zone. This finding when properly utilized by the major stakeholders in Enugu state education sector could possibly help to address the current trend of inadequate ICT skills of secondary school teachers for effective instructional delivery in line with the current struggle for e-learning and advancement technological development.

\section{RECOMMENDATIONS}

That the State government through its ministry of education should help package the identified ICT skills items in computer appreciation, word processing, internet communication and spreadsheet into programmes for re-training the teachers for ICT skill update in the State.

That the identified ICT skills should be used by curriculum planners at State and federal levels to further improve the existing curriculums at secondary in the State and the nation in general. That government should ensure adequate provision of the required ICT facilities in the school for use by the teachers.

That, as part of improved welfare package of teachers, government should provide secondary school teachers with personal laptops which will further facilitate ICT skill acquisition of the teachers for effective use of ICT facilities for instructional delivery in the area. 
Nwosu Ogochukwu F et al., Sch J Eng Tech, Apr, 2021; 9(4): 46-50

\section{REFERENCES}

1. Ugo CA. Effects of computer-assisted language learning on students' achievement in English language. Ph.D Thesis submitted to Faculty of Education Nnamdi Azikiwe University, Awka; 2018.

2. Opara OJ. Fundamentals of word processing. Barloz Publishing Inc, Owerri, Nigeria; 2012.

3. Odia NN. Administrative theory. Enugu: John Jacob's Classic Publishers Ltd; 2009.

4. Orji UU. Competencies in office information system for a sustainable secretarial studies programme in the $21^{\text {st }}$ century; a critical Analysis on Business Education Journal, 2014; 2(1):253258.

5. Yusuf M. Effects of computer aided instruction (CAI) on secondary school performance in biology. Journal of education Technology, 2010; 9(1).

6. Burnip L. ICT mediated study and teachers. Do they have the infrastructure? Australlian Journal of Educational Technology, 2006; 22(3): 355-374.

7. Igbeaku GI. Issues in development administration. Enugu: Cheston Agency; 2018.
8. Onah BI. Strategies for enhancing the accessibility and use of information and communication technologies in colleges of education, Unpublished Masters Thesis. Department of Computer education, University of Nigeria Nsukka; 2008.

9. Ogunsola LA. Information communication technologies and the effects of globalization: Twenty-first century "digital slavery" for developing countries-myth or reality? Electronic Journal of Academic and Special Librarianship, 2005; 6 (1)1-10.

10. Kyunghoon. The study of revised computer selection subject curriculum in secondary school. Korea Institute of Curriculum and Evaluation (KICE), Seoul; 2006.

11. Olakulehin FK. Information communication technologies in teachers training and professional development in Nigeria. Turkish Journal of Distance Education TQDE, 2007; 8(1), 133-142.

12. Inwent. E-learning development and implementation: Course Information and Documentation. Bonn: Inwent; 2004.

13. Eneje FS. Computer use and applications, Nsukka: Godjiksons Publishers; 2008. 